\title{
About the series
}

\section{Professor Robert M. Solow}

The Cournot Centre for Economic Studies is an independent French-based research institute. It takes its name from the pioneering economist, mathematician and philosopher Antoine Augustin Cournot (1801-77).

Neither a think-tank nor a research bureau, the Centre enjoys the special independence of a catalyst. My old student dictionary (dated 1936) says that catalysis is the 'acceleration of a reaction produced by a substance, called the catalyst, which may be recovered practically unchanged at the end of the reaction'. The reaction we have in mind results from bringing together (a) an issue of economic policy that is currently being discussed and debated in Europe and (b) the relevant theoretical and empirical findings of serious economic research in universities, think-tanks and research bureaux. Acceleration is desirable because it is better that reaction occurs before minds are made up and decisions taken, not after. We hope that the Cournot Centre can be recovered practically unchanged and used again and again.

Notice that 'policy debate' is not exactly what we are trying to promote. To have a policy debate, you need not only knowledge and understanding, but also preferences, desires, values and goals. The trouble is that, in practice, the debaters often have only those things, and they invent or adopt only those 'findings' that are convenient. The Cournot Centre hopes to inject the findings of serious research at an early stage.

It is important to realize that this is not easy or straightforward. The analytical issues that underlie economic policy choices are usually complex. Economics is not an experimental science. The available data are scarce, and may not be exactly the relevant ones. Interpretations are therefore uncertain. Different studies, by uncommitted economists, may give different results. When those controversies exist, it is our hope that the Centre's conferences will discuss them. Live debate at that fundamental level is exactly what we are after.

There is also a problem of timing. Conferences have to be planned well in advance, so that authors can prepare careful and up-to-date texts. Then a publication lag is inevitable. The implication is that the Cournot Centre's conferences cannot take up very short-term issues of policy. Instead, a 
balancing act is required: we need issues that are short-term enough so that they are directly concerned with current policy, but long-term enough so that they remain directly relevant for a few years.

I used the words 'serious research' a moment ago. That sort of phrase is sometimes used to exclude unwelcome ideas, especially unfashionable ones. The Cournot Centre does not intend to impose narrow requirements of orthodoxy, but it does hope to impose high standards of attention to logic and respect for facts. It is because those standards are not always observed in debates about policy that an institution like the Cournot Centre has a role to play. 


\section{OTHER BOOKS IN THE COURNOT CENTRE SERIES}

2007. Augustin Cournot: Modelling Economics

Edited by Jean-Philippe Touffut

Contributors: Robert J. Aumann, Alain Desrosières, Jean Magnan de Bornier, Thierry Martin, Glenn Shafer, Robert M. Solow, Bernard Walliser

2006. Advancing Public Goods

Edited by Jean-Philippe Touffut

Contributors: Patrick Artus, Avner Ben-Ner, Bernard Gazier, Xavier Greffe, Claude Henry, Philippe Herzog, Inge Kaul, Joseph E. Stiglitz

2005. Corporate Governance Adrift: A Critique of Shareholder Value Michel Aglietta and Antoine Rebérioux

2004. The Future of Economic Growth: As New Becomes Old Robert Boyer

2003. Institutions, Innovation and Growth: Selected Economic Papers Edited by Jean-Philippe Touffut

Contributors: Philippe Aghion, Bruno Amable, with Pascal Petit, Timothy Bresnahan, Paul A. David, David Marsden, AnnaLee Saxenian, Günther Schmid, Robert M. Solow, Wolfgang Streeck, Jean-Philippe Touffut 